\title{
11. Championing Change in a Highly Contested Policy Area: The literacy reforms of David Kemp, 1996-2001
}

\author{
Wendy Jarvie and Trish Mercer
}

When John Howard won a landslide victory over Paul Keating in March 1996, his junior Minister for Schools, Vocational Education and Training was David Kemp. ${ }^{1}$ Portrayed by the media as a dry Liberal with conservative economic and social views, Kemp was a well-known political figure. His hands-on experience as a senior adviser in Malcolm Fraser's prime ministerial office in the late 1970s had been complemented by his time as a politics professor at Monash University, where he published a study of Australian politics which combined a theoretical analysis with his insider knowledge of Australian politics and government (Kemp 1988).

In the radical schooling reform agenda that Kemp would pursue, improved literacy attainment of Australian school children, particularly in their primary years, would represent a core element, if not the centrepiece. His approach displayed a singularity of purpose and a clear understanding of how to employ the pushpull levers of the Commonwealth's federal powers. ${ }^{2}$ The Howard government, notwithstanding what has been seen as a traditional Liberal commitment to federalism, would become a strongly central government, partly attributable to the increasingly antagonistic Commonwealth/state environment — by 2002, all state and territory governments were Labor-controlled. Howard himself articulated his approach in terms of an 'aspirational nationalism' (Anderson and Parkin 2010, p. 97). In Liberal eyes, Commonwealth intervention in state policy areas was justified if it was supporting key Liberal objectives of individual decision-making and free markets (Kemp 2013). Indeed, Commonwealth Liberal intervention in education had long been manifest in schooling policy, beginning with Prime Minister Menzies' funding of science laboratories in schools in the 1960s.

Hollander and Patapan (2007) have labelled the defining characteristic of the Howard government and the preceding Hawke-Keating governments as 'pragmatic federalism', in that both tended to directly engage with pressing

\footnotetext{
1 David Kemp was promoted the following year to the portfolio ministry of Employment, Education and Training. This mega portfolio (DEETYA) was later reduced to Education, Training and Youth Affairs (DETYA) when Employment was established as a separate ministry with Industrial Relations.

2 While this paper will focus on Kemp's literacy reforms, numeracy improvement was also a key goal and was pursued concurrently.
} 
problems without resort to larger theoretical concerns. While still influenced by ideas and values, it was the convergence of an identified problem with an opportunity for political engagement which served to create the window for a policy solution to emerge, and this tended to favour the Commonwealth over the states in policy outcomes (Hollander and Patapan 2007, pp. 280-281, 283285). Kemp undoubtedly had a deep philosophical adherence to Liberal tenets and in his pursuit of literacy policy reform from 1996 was fully prepared to adopt an interventionist approach with state education systems. In bringing together the streams of problem, politics and policy, his approach appears to have been characterised by a pragmatic 'problem-defined and problem-driven' focus (Hollander and Patapan 2007, p. 291), which we will show was illustrated through the following features:

- First, his identification of an urgent literacy problem and his readiness to seize on the opportunities in government to capitalise on recent developments in educational and public policies;

- Secondly, the importance he attached to marshalling a supportive evidence base and communicating the literacy problem to a public audience, notwithstanding the contested nature of this evidence;

- Thirdly, the influence of the political environment in terms of the political backing he received for his reform focus, particularly from Prime Minister Howard, and the broader alignment with Howard's federalist ambitions and first- and second-term priorities;

- Fourthly, the deliberate carrot and stick tactics which he employed to secure the support, or at least reluctant acquiescence, of both government and nongovernment education sectors to his policy solutions; and

- Finally, the underpinning partnership between the Minister, his Chief of Staff and senior departmental officers which provided the administrative mobilisation to embed these policy solutions into a lasting reform agenda.

Kemp's approach, together with his department's focus on implementation, illustrates the importance of having both policy and administrative champions, particularly in such a contested policy area. In examining his literacy reforms, the authors have drawn on interviews with several key players: Kemp himself, senior Commonwealth education department bureaucrats, two state education department directors-general, and the researcher who was heavily involved in literacy assessment. ${ }^{3}$

3 While not taking any role in the literacy reforms, the authors worked at the Senior Executive Service level in Kemp's department during the early part of the period: Wendy Jarvie worked from 1997 to 1998 in Analysis and Evaluation Division; Trish Mercer briefly in the Schools area in 1996 before she became an Area Manager in Queensland. We are grateful to Bill Daniels (a former DEETYA senior officer and, from July 2001, Executive Director of the Independent Schools Council of Australia) who provided access to the minutes of the Board of Management meetings of the Council for 1996 to 2001, which provided useful insights into the perspectives of the Independent schools sector. 


\section{Positioning literacy as an urgent policy problem}

Kemp's literacy agenda was based on his belief that individuals had to take responsibility for their own success, and that the role of education policy is to ensure that individuals have the right skills to achieve this (ABC 1999, pp. 3, 11). Since the early 1990s, he had been developing and articulating Liberal educational policy. In July 1991, speaking at the National Press Club as Shadow Minister for Education, he had asserted that 'no one area of national policy is more important for Australia to get right than education', and that gaining an internationally competitive edge in education was as important as acquiring such competitiveness in transport, communication or the waterfront (Kemp 1991).

By 1996, in the Coalition's election platform, this had crystallised into a commitment to work in a 'partnership approach' with the states on a National Literacy and Numeracy Strategy, including building a national database on literacy and numeracy standards in Australian schools (Liberals and Nationals Election Platform 1996, pp. 1, 3). In his early ministerial speeches, he drew attention to the social and economic costs of inadequate language and literacy skills (Kemp, Media Release: 'A National Literacy Goal', 21 June 1996); by the next year, he was hailing literacy as 'the key equity issue in education today' (Kemp, Media Release, 16 September 1997). This prioritising of literacy intrigued many media commentators, who began to describe him as a 'crusader' (Channel Nine 1999). Kemp himself nominated his motivation as having come from the feedback he had received in his early days as Minister from industry and 'from those who feel that their own literacy is not what it should be', and there was also the personal element of being the father of two young children (Kemp, Media Release, 5 September 1999; The Australian, 6 February 1999, p. 8).

In concentrating on literacy achievement, Kemp capitalised on recent developments in Australia and internationally. From the mid-1980s, interest in measuring the performance of students and of education systems through standardised literacy and numeracy testing had been increasing, particularly in countries such as the United Kingdom and United States. This standardsbased agenda had itself been influenced by the broader global trend to reform public sector management and to increase accountability (Watson 2011, pp. 7-8). Within Australia, different state governments had begun to introduce standardised assessment testing of students in their education systems, notwithstanding strong opposition from the Australian Education Union (AEU) (Peach 1998, p. 8; The Australian, 6 August 1997, p. 11). The capability now existed, through psychometric measurement techniques, to enable the equating of state tests to derive national data. To capitalise on this, in 1995 the new and influential Report of Government Service Provision produced for the Council of Australian Governments had signalled strong interest in developing such 
nationally comparable data on student learning outcomes, although there was a pragmatic awareness that this would require a significant commitment from both Commonwealth and state governments to be implemented (Dowling 2008, p. 3; Steering Committee for Review of Commonwealth/State Service Provision 1995, pp. 199-201). In Kemp's early months, a first move in this direction was taken when senior education officials agreed in May to recommend to their ministers that literacy and numeracy benchmarks should be developed to indicate the student outcomes expected for particular years in schooling (Peach 1998, pp. 8-10). Kemp's reform focus on literacy and measurement was seen as being 'absolutely on the right track' by the influential directors-general of education in New South Wales (Ken Boston) and Victoria (Geoff Spring) (Boston 21 February 2013; Spring 25 March 2013).

\section{Marshalling the evidence}

As a new minister, Kemp sought to engage with key stakeholders such as the cross-sectoral Australian Primary Principals' Assocation (Kemp, Media Releases, 17 April 1996, 29 May 1996, 19 July 1996). As early as May, he had quietly sought the views of the peak independent schools body (National Independent Schools Council) as to 'reasonable accountability requirements' for national data collections on school and student performance (Board Minutes 10 May 1996).

This approach was an early indication of his determination, well before 'evidencebased policy' had acquired political currency, to collect an authoritative evidence base on current literacy and numeracy performance in order to galvanise public debate. The literacy agenda itself was hardly new: an emphasis on literacy policy and accompanying programs of assistance had been a recurring feature under the Hawke-Keating Labor governments through the 1990s (Harrington and McDonald 1999). But reliable data had not been available. Initially, Kemp relied on the higher end of estimates in a 1993 House of Representative Standing Committee on Employment, Education and Training report, that between 10 and 20 per cent of children finished school with literacy problems. He used this statistic in unveiling a 'Literacy Strategy', with five key steps, at the Australian College of Educators' Conference in June 1996 and foreshadowed that he would be seeking state and territory support for his fifth step, a national goal that every child leaving primary school should be able to read, write and spell at an appropriate level (Harrington and McDonald 1999, p. 6; Kemp Media Release 21 June 1996). This was indeed agreed as a national goal on 18 July at Kemp's first meeting of the Ministerial Council for Education, Employment, Training and Youth Affairs (MCEETYA). Ministers moreover agreed to support this goal through the development of common literacy benchmarks for Year 3 and Year 5 students and, importantly, the associated determination of levels of performance to be met in reading, writing and other essential aspects of literacy 
(MCEECDYA, 17-18 July 1996). Thus at his first Commonwealth/state meeting, Kemp had achieved progress towards assessing not only student outcomes but also potentially the performance of the education systems themselves. He had also signalled a recurring political tactic of outing his agenda before discussion with his ministerial colleagues.

The cornerstone of Kemp's evidence base would be the first comprehensive literacy survey of Australian primary school children in 16 years - in April, he pledged support for this survey, commissioned as part of the Keating Labor government's 'Working Nation' reforms (Kemp, Media Release, 17 April 1996; Comber et al. 1998, pp. 18, 25). Conducted in August 1996 by the Australian Council for Educational Research (ACER) with support from the schooling systems, the unions and professional associations, the National School English Literacy Survey (hereafter the National Literacy Survey) involved nearly 7,500 children and an additional 800 Indigenous sample, at a cost to the Commonwealth of \$2.6 million. This survey would establish reliable, national baseline data on the literary performance of children in Years 3 and 5 of schooling which would support the development of the national benchmarks agreed by MCEETYA in their July meeting (MCNSELS 1997, pp. 5, 250-252, 309).

Kemp, however, was not content to wait on the survey's results. In October 1996, in a major policy statement delivered at the Centre for Independent Studies, he drew on an ACER comparative analysis constructed from youth longitudinal surveys which indicated that, in 1995, 30 per cent of 14-year-old students did not have adequate basic literacy skills, as against 28 per cent in 1975 . Describing this relatively small increase as 'alarming', he attributed these results to a 'cult of secrecy' which limited the ability of schools to improve student academic performance and challenged his state counterparts to publish their schools' academic results. Not surprisingly, Kemp's claims attracted considerable media interest and, concurrently, academic and union opposition to what they saw as his support for the introduction of school rankings and flawed analysis (Kemp, Media Release, 22 October 1996; The Australian, 22 October 1996, p. 1, 23 October 1996, p. 15, 24 October 1996, p. 10; Martin 1997, p. 9). Politically, however, this challenge could not be ignored, demonstrated by New South Wales premier Bob Carr's announcement that, given these 'very, very disturbing' figures, his state would consider widening a pilot project to test Year 7 literacy in 1997 (The Australian, 23 October 1996, p. 3).

On the eve of the next MCEETYA meeting on 14 March 1997, the Minister announced that he would be asking state education ministers to endorse a national literacy test for Year 3 students and that he would consider withholding 
schools funding if literacy levels failed to improve. ${ }^{4}$ Notwithstanding hostile media reactions from several state ministers and the Liberal Premier of Western Australia, MCEETYA nevertheless agreed to the Commonwealth's proposal for a National Literacy and Numeracy Plan, including literacy and numeracy tests for both Year 3 and Year 5 students from 1998 - duly reported in The Australian as 'a historic agreement' between Commonwealth and state (with support also from the Catholic and independent school sectors). The states would continue to conduct their own tests with national benchmark data derived from their results. This was the first of a series of key MCEETYA meetings where Kemp arranged for either a ministerial-only session, or preceding dinner so that ministers could negotiate directly on this sensitive issue; having secured their agreement to a testing regime, he then retreated from his threat to tie federal funding to literacy improvement (The Australian, 12 March 1997, p. 3, 15 March 1997, p. 1; Dowling 2008, p. 4; MCEEDYA, 14 March 1997). ${ }^{5}$ In contrast to such tough negotiations, Kemp's strategy with the non-government schools sector was more conciliatory, with separate discussions conducted by both the Minister and his key bureaucrats with Independent schools' representatives. The implications of national testing was a sensitive issue for the sector and in May 1997 they were only prepared to provide a holding response to Kemp's request for their support (National Independent Schools Council Board Minutes, 8 November 1996, 21 March 1997, 23 May 1997).

\section{Publicising the evidence}

As 1997 progressed, the political tensions in the schools sector continued to rise, highlighted at a forum on literacy in July to which Kemp invited 28 academic leaders. One of the documents for the day, entitled Australian Literacies and prepared by academic experts, directly challenged Kemp's position by stating unequivocally that there was 'no general literacy crisis in Australia' (Lo Bianco and Freebody 1997, p. xvi). Literacy had become a highly contested policy area and Kemp was viewed by many in the education community as having manufactured a literacy crisis and attached at least some of the blame to literacy teaching (Gill 1998; Martin 1997, pp. 8-10; Comber et al. 1998, pp. 18, 19). Early in 1998, an article by four prominent academics was published which closely analysed Kemp's public statements and compared the Howard education agenda with that of the former Labor government. The authors were dismissive of the

\footnotetext{
4 Kemp had supported his announcement by releasing yet another piece of ACER research, based on a five-year study of the education and career paths of 2,000 Australian teenagers, which demonstrated the disadvantage that young people without adequate literacy and numeracy faced in the education, training and labour market: Kemp, Media Release, 11 March 1997.

5 This ministerial-only meeting was reported in The Australian and both Dr Evan Arthur (then head of the Literacy and Special Programs Branch in DEETYA) and Dr Kemp have recalled that this was a deliberate tactic, as were the preceding ministerial dinners, to secure agreement to the Commonwealth's agenda: Arthur 2012; Kemp 2012.
} 
various postwar 'literacy crises' that they saw as indicative of governments facing major social, economic and cultural change and discerned a deeper, more political motivation in Kemp's agenda: 'the current literacy crisis has been deployed to undermine community confidence in public schooling, and at the same time deflect attention and responsibility from material problems of poverty and youth unemployment' (Comber et al. 1998, pp. 19-27). ${ }^{6}$ Although others were not so forceful in their criticisms of Kemp's literacy preoccupation, the views of Comber et al. on the negative aspects of testing were shared by many colleagues. ${ }^{7}$

This academic reaction had been stimulated at least in part by a media debate which played out in September 1997 following the simultaneous release by the Commonwealth of two reports on the results of the National Literacy Survey. The first, 'Mapping Literacy Achievement', was prepared by the Survey's Management Committee which included education system representatives, the unions and ACER. It was welcomed by the education community as a comprehensive map of literacy performance (MCNSELS 1997, pp. x, 3-4; Gill 1998, pp. 13-14). The main message was that the majority of students were achieving well, although there was a significant spread of achievement. Central to its approach was a comparison of student survey performance in relation to an indicative range of student achievement in which might lie the new draft MCEETYA benchmarking standards released in June and developed by a Benchmarking Task Force chaired by the Director-General of Education Queensland, Frank Peach. The conclusion in this report was that only six and four per cent of Year 3 students were performing below this draft benchmark range in writing and reading respectively, rising to 15 and 21 per cent for Year 5 students. According to the Commonwealth representative (Evan Arthur), however, the Management Committee had earlier commissioned ACER to develop a more precise mapping of the draft benchmarks against the survey's results, but had subsequently chosen to employ an indicative range in presenting these results (Arther 2011). ${ }^{8}$

6 This article was published in a book edited by Alan Reid, which focused on what was described as the contemporary debate about the survival of the public education system. Comber et al. 1998, p. 31, for example argued that 'literacy' was functioning as a metaphor for 'schooling' and specifically public schooling: Reid 1998, pp. xi, xiii.

7 In April 1997, 50 Victorian literacy experts (from peak bodies and universities) sent a letter to Kemp, arguing that the expenditure on national literacy testing would be better spent on teacher training and professional renewal: The Australian, 23 April 1997, p. 39. For other examples of opposition to testing, see The Australian, 20 July 1999, p. 6; 3 April 2000, p. 15; Professor Alan Luke and Dr Brian Comber quoted on ABC 1999, pp. 7, 8.

8 While the methodology employed was technically complex, the choice of an indicative range in presenting the results would appear to have overstated achievement, when ACER's methodological analysis (reported in Appendix 3) is examined more closely. The report compares achievement under the existing English curriculum profiles to the range expected in the draft benchmark standards. ACER reported that not all the students within the particular profile (Level 2 for both writing and reading in the case of Year 3 students) which contained the draft writing and reading benchmarks would have met the appropriate benchmark - 
Such methodological reliance on an indicative range, not surprisingly, was anathema to Dr Kemp, who was determined to present a clear line (i.e. an exact score) in the survey results as to who was above or below the draft benchmarks; his recollection is that he was 'shocked' that 'nowhere was there any analysis that could tell the community how many students had sufficient literacy to allow them to continue education' (Kemp 2012). Geoff Masters has recalled that Kemp was very clear that the survey report would not be released until ACER had analysed the results in terms of what was an acceptable level of literacy performance. To this end, Masters and Margaret Forster of ACER developed what they described as 'clear performance standards in reading and writing' by utilising the draft benchmark standards to calculate a minimum score that would constitute a satisfactory performance for the student's age or year group. Under this approach, published as 'Literacy Standards in Australia', very different results were reported: 28 per cent of Year 3 and 33 per cent of Year 5 students did not meet the identified performance standards for writing; and 27 per cent of Year 3 and 29 per cent of Year 5 students did not meet the standards for reading. Girls met the standard more often than boys, but only a very low percentage of Indigenous students met them. ${ }^{9}$

These differing presentations of the survey's results would have been sufficient to ensure strong media interest and robust debate at the next MCEETYA meeting. However, Kemp's decision to air the findings on Channel Nine's 60 Minutes current affairs program on 14 September 1997, some two days after he had provided 'Literacy Standards in Australia' to his ministerial colleagues, created what the AEU called 'Literacy Hysteria Week' and was later described as 'sensational [media] coverage', both electronic and print (Martin 1997, p. 8; The Australian, 6 February 1999, p. 8). The media focused on Kemp's portrayal of 'a serious literacy problem', with nearly one-third of primary children unable to read or write at an adequate standard, requiring urgent 'national cooperative effort' (Kemp, Media Release, 15 September 1997). Nearly two years later, the acrimonious response this had produced, particularly from state education ministers, was manifest on the ABC's Four Corners program (titled 'War of Words') with critics such as Phil Gude (the Victorian Liberal Education Minister) standing by his accusation at the time that Dr Kemp was 'deliberately and mischievously manipulating data to portray literacy at a perilous level' (ABC 1999, p. 7; Comber et al. 1998, pp. 3, 19). Peach, the bureaucrat heading the

for example, at least some of the 42 per cent of Year 3 students assessed at English Profile Level 2 would not have met the Year 3 draft reading benchmark range as this was located towards the upper end of this Level 2 : MCNSELS 1997, pp. iv, vi, Appendix 3, 314-329.

9 ACER, for whom this was a very sensitive exercise in terms of reputational regard, were careful to report that it was the Minister who had asked for an exact score, in the belief that how schoolchildren were performing in relation to such a performance standard 'would be useful information for the Australian community': Masters and Forster 1997, pp. 10-12, 15, 19, 22; Kemp, Media Release, 15 September 1997; Masters 2012. 
Benchmarking Taskforce, had noted pointedly in May 1998 at an educational conference that 'Literacy Standards in Australia' had 'caused considerable national concern by its use of what some argued were arbitrary and highly judgemental decisions' in attempting to align the survey's reading and writing results against the draft reading and writing benchmarks for Years 3 and 5 (Peach 1998, p. 13). Yet notwithstanding these strong criticisms, the statistics in 'Literacy Standards in Australia' would be cited not only by the media and other commentators but also in significant reports such as the Productivity Commission's Report on Government Services (The Australian, 22 September 1997, p. 1; SCRRCSSP 1998, p. 42; Argy 1998, pp. 120-121; Alloway and Gilbert 1998, pp. 249, 252). ${ }^{10}$

In an attempt to regain the initiative, state and territory ministers met without Kemp on 22 September and issued their own ten-point plan to advance previously agreed recommendations in the National Literacy and Numeracy Plan. Kemp, however, rejected out of hand the states' request for an additional \$513 million in federal funding over the next four years (Peach, 1998, p. 13; The Australian, 22 September 1997, p. 1). By November, when Arthur briefed independent schools' representatives, there appears to have been bureaucratic agreement on key assessment details but there remained 'State ministerial concern about the public presentation of data' (National Independent Schools Council Board Minutes, 14 November 1997). The draft literacy benchmarks for children in Year 3 and Year 5 were finally approved by all education ministers in the following year and, significantly, included a line drawn across the range to represent satisfactory performance (MCEECDYA, 23 April 1998; Arthur 2011).

While Kemp earned the ire of many state education ministers and bureaucrats as well as academics for his political use of literacy data, it is nonetheless apparent that he devoted considerable resources and energy to accumulating an evidence base on literacy. Those who worked closely with him have remarked on this determination. Professor Masters has recalled how Kemp, with his social science training, 'was focused on evidence, he valued research and he wanted to use it' (Masters 2012). Indeed, John Roskom, his Chief of Staff from 1996 to 1998, described his boss as having a deep belief 'that his opponents, if provided with sufficient evidence, could be won over ${ }^{11}{ }^{11}$ Moreover, he was well able to analyse and interpret the highly technical detail associated with testing and benchmark

10 Kemp does not appear to have directly rebutted any of the criticisms of how he employed the survey data, but Frank Devine (a supportive journalist presumably briefed by Kemp's office) reported in late September that the analysis by ACER in regard to the survey results and the draft benchmarks had been done at the request of the management committee for the survey (the 'Harrington Committee') but had then been buried in the Appendix to 'Mapping Literacy Achievement': The Australian, 25 September 1997, p. 13.

11 Roskom made these comments when Kemp was retiring from federal politics in 2004: The Age, 17 July 2004. In a similar vein, Steve Sedgwick (the DEETYA and then DETYA Secretary at this time) has recalled how Dr Kemp would look to build the case publicly and then seek to make common cause with his state ministerial colleagues: Sedgwick 2012. 
development - an asset he exploited in ministerial council meetings (Arthur 2012; Sedgwick 2012). It is an open question as to whether Kemp would have focused so strongly on evidence if it had not fitted his purpose. Certainly, by publicly releasing the separate report he had commissioned on the National Literacy Survey's results on a populist TV show, Kemp the politician fully intended to create controversy and a public debate which would promote his agenda of locking state ministers into support for a national testing and benchmark regime and presenting this as a Commonwealth driven initiative.

\section{Getting the Commonwealth politics right}

Kemp's preoccupation with evidence was not shared by his Prime Minister. Paul Kelly has depicted the Howard Cabinet as more often than not seeing 'the academy as unfavorably disposed towards its objectives' with Howard employing research and advice 'to realize his aims'. ${ }^{12}$ In terms of the overarching directions of schooling policy, however, the Minister and Prime Minister were very closely aligned. The Howard government was more centralist than its predecessors and Kemp, while genuflecting to the primary responsibility for schooling held by the states, had defined a formative role for the Commonwealth. He saw this as based on the 'strong national interest in the educational outcomes of Australia's schools', manifested not only in the Commonwealth's significant funding contribution, but also through the indirect cost of 'school failure' borne through unemployment benefits and social programs (Kemp, Media Release, 21 April 1997).

In education, the broader political agenda favouring privatisation, competition and choice was manifested in the Howard government's user choice approach to funding of vocational education, and the introduction of performance-driven funding of higher education research. ${ }^{13}$ In schools education it was evident in the removal of restrictions on the establishment of new private schools, emphasis on quality and performance standards and expansion of non-government school funding. ${ }^{14}$ Howard articulated this focus in 2007 when he contended that quality in schooling 'demands choice, diversity, specialisation, transparency and competition.' Support for testing of students' knowledge and more transparency to empower parents were examples he cited of his 'traditional views' which he contrasted with the 'postmodernist values' of educational theorists and some Labor governments (The Australian, 16 May 2007, p. 14).

12 Kelly, as Editor-at-Large of The Australian, is a respected commentator on public policy. This was an address to the Institute of Public Administration's Council: Kelly 2006, p. 15.

13 See, for example, the White Paper on higher education research funding: Kemp 1999.

14 The non-government school funding policies of the Howard government are well described by Wilkinson et al. 2007, pp. 151-180 and Paul Kelly, The Australian, 16 May 2007, p. 14. 
In 1999, the political significance of the literacy reforms was articulated publicly when The Australian labelled this as 'a Howard battlers' issue because the Howard battlers were missing out on literacy. ${ }^{15}$ Given the extent to which the schooling reform priorities pursued by Kemp dovetailed with the Coalition's broader political agenda, it is unsurprising that Kemp was frequently reported as having the strong support of his Prime Minister and that Howard regularly praised Kemp's literacy reforms (see, for example, The Australian, 22 December 1997, p. 11, 6 February 1999, p. 8; AustralianPolitics.com 2001). Certainly Kemp's skill at selling the government's policies was seen by some of his opponents as responsible for his promotion to the Cabinet ministry of Employment, Education and Training in October 1997 (Martin 1997, p. 11).

\section{Getting state agreement}

\section{Getting state agreement: The carrot}

Aside from such marketing abilities, Kemp was determined to exert influence through all the avenues available to him as a federal minister. In his Foundations for Australian Political Analysis, he cited persuasion, grants and physical coercion as some of the most important social mechanisms for political strategies (Kemp 1988, p. 7). As a Minister, he was successful in quarantining schools' programs from the tough funding cuts in the early Costello budgets and in securing some additional funding commitments for literacy and numeracy initiatives. For example:

- The government's first budget, in August 1996, included an additional \$45 million for a National Literacy and Numeracy Strategy;

- During 1997, there were targeted funding announcements, such as $\$ 7$ million for literacy training for primary school teachers and \$6.2 million for English as a second language tuition for Indigenous students; and,

- \$1 million to establish an annual National Literacy Week was announced in March 1999, and later in the 1999 budget two significant 1998 election commitments were funded, with $\$ 47.1$ million for literacy initiatives in middle schooling and \$84 million for MCEETYA's National Literacy and Numeracy Plan (Kemp, Media Releases, 20 August 1996, 15 September 1997, 1 October 1997, 16 March 1999, 11 May 1999).

Such funding largesse was aimed as much at the diverse non-government school community as the government sector. Securing their agreement to

15 According to the reporter Catherine Armitage, this issue was discussed regularly at cabinet's employment subcommittee meetings: The Australian, 6 February 1999, p. 8. 
come on board with national assessment testing of all students involved sensitive negotiations and was seen in the media as largely a quid pro quo for the substantial funding increases available for non-government schools under the revised socio-economic status recurrent funding arrangements (Channel Nine 1999). ${ }^{16}$ However, the Commonwealth drew the line at meeting the very substantial costs for government and non-government systems in administering the new national tests, insisting that education authorities needed to reassess their funding priorities. Kemp was adamantly of the view that literacy and numeracy should be the 'first call on the education dollar' (The Australian, 12 March 1997, p. 3). ${ }^{17}$

\section{Getting state agreement: The stick}

In his study of Australian politics, Kemp had highlighted the Commonwealth's greater capacity in federal conflicts to extend its authority (Kemp 1988, p. 143). In office he worked to expand the Commonwealth's influence in the schooling sector, with education becoming a prominent example of the government's willingness to employ conditionality in Commonwealth grants as a vehicle to achieve policy priorities (Anderson and Parkin 2010, p. 101). During 1996 and 1997, Kemp had publicly advocated that individual schools should be required to publish their literacy performance results as a public accountability measure (The Australian, 24 October 1996, p. 10; Comber et al. 1998, p. 27: Kemp, Media Release, 21 April 1997). He was also willing to employ — or at least to threaten to employ - the Commonwealth's financial power as a lever to compel state and territory governments to implement his literacy standards. Having created a media furore in September 1997 with his 60 Minutes appearance and the release of 'Literacy Standards in Australia' with its alarming statistics, Kemp almost immediately announced that the Commonwealth would impose a condition on future access to literacy program funding, thus enacting a threat he had raised earlier in the year - states and territories would be required to provide a detailed plan on how schools would ensure that their students were reading and writing adequately by the end of Year $3 .^{18}$

These plans became a regular requirement for education systems to access Commonwealth literacy funding. By mid-1999, there was media speculation that Kemp was investigating how to extend this by linking individual school funding

16 Reflecting these sensitivities, Kemp's department reported in 1999 that all government and most non-government education authorities had participated in literacy benchmark exercises for Years 3 and 5: DETYA 1999.

17 Despite Kemp's views, later in 1997 there were discussions between DETYA and an Independent Schools representative concerning funding support for Independent schools, but this does not appear to have eventuated: National Independent Schools Council Board Minutes, 26 August 1997.

18 Notwithstanding Kemp's interest in ensuring that the literacy performance of individual schools was made public, the reporting agreed by MCEETYA was only at the state level (without even any differentiation by system): Kemp, Media Release, 16 September 1997. 
to compliance with the literacy and numeracy benchmarks (The Australian, 19 July 1999, p. 4; 20 July 1999, p. 6). Throughout 2000, the independent schools sector was monitoring the strengthened accountability requirements as a 'major issue' for their schools, with concerns at the discretionary powers reserved for the Minister (National Independent Schools Council Board Minutes, 26 February, 26 May, 25 August, 6 October and 24 November 2000). Kemp may have been partially motivated by his exasperation at the delays in implementing MCEETYA's decisions from 1996-97 to develop and report progress against literacy and numeracy benchmarks for Year 3 and Year 5 students. There was a long and tortuous process of equating the different state and territory tests to enable national comparability; ministers only finally reached agreement in May 1999 that such tests needed to contain more common elements to achieve such comparability (The Australian, 3 May 1999, p. 17; 19 July 1999, p. 4). Finally, in early 2000, the first report (restricted to the Year 3 reading component) was released, with the results indicating that some 87 per cent of Australian Year 3 students had achieved the benchmark — such a striking improvement on the 1996 survey results that Professor Peter Freebody of Griffith University drily remarked that 'the latest round of testing seems to indicate either that [literacy levels] improved very dramatically in a very short period of time or that [Kemp's claim of a "literacy crisis"] was an overstatement' (ABC 1999, p. 7; The Australian, 17 March 2000, p. 15). ${ }^{19}$ An alternative interpretation could be that the questions in the new benchmark testing had been 'dumbed down', given that ACER's Geoff Masters was publicly quoted as claiming that state educators were pressuring his experts to accept easier questions. Both Kemp and his state colleagues, however, were quick to deny that this was occurring (The Australian, 25 February 2000, p. 1). ${ }^{20}$

Later in 2000, Kemp secured an important amendment to the Schools States Grants legislation so that education authorities, to receive funding under the Commonwealth's literacy and numeracy program, would be required to report against performance measures and targets for literacy and numeracy. National reporting of state performance was now a legislated Commonwealth requirement - seen as an example of the Howard government's engagement in 'regulatory' federalism, under which funding access was conditional on state compliance with central policy demands (Vromen et al. 2009, p. 309). Some state ministers contended that Kemp had threatened them with the withdrawal of funds from low performing schools. Both the former directors-general that we interviewed recalled that the ministerial-only meetings were 'bunfights': Geoff Spring

19 Kemp himself had predicted in 1999 that the result would be in the low-to-mid-80s.

20 In January 2005, the Sydney Morning Herald reported that a dyslexic Year 3 student, who was in the bottom 17 per cent in the NSW Basic Skills test and was said to be two years behind his peers, nevertheless met the literacy benchmark for Year 3. In our interview in 2012, Kemp indicated that he now has doubts as to whether the process employed at the time to establish equivalences across the various state tests was highly accurate and effective: AUSPELD 2005, p. 3; Kemp 2012. 
indicated that Kemp used his negotiating strengths 'to imply that funds were at risk if they didn't co-operate' (Spring 2013; Boston 2013). Nevertheless, Kemp was adamant when interviewed by the ABC in August 1999 that he had never threatened to withdraw funding and that his interest was in identifying schools so that they could be helped by the relevant state system. ${ }^{21}$

While state ministers resented his tactics, Kemp was often publicly regarded as having brought a sustained spotlight onto an important issue in school literacy (Argy 1998, pp. 120-121; The Australian, 6 February 1999, p. 8; Channel Nine 1999). Despite having ranged against him what the ABC Four Corners program described as a 'formidable array' of opponents from political, bureaucratic, academic and professional quarters, he was seen as having successfully corralled all of the states and territories into accepting an ongoing system of literacy testing and public reporting by engaging the weight of public opinion (ABC 1999, p. 7). During his time as Minister, virtually every MCEETYA meeting included resolutions on literacy and/or numeracy, as ministers worked through the complex issues involved in establishing national standards for the benchmarks and reporting framework and then progressively extending it to encompass both literacy and numeracy for schoolchildren in Years 3, 5 and 7 (and later 9). ${ }^{22}$ By 2000, furthermore, the introduction of national testing had become a bipartisan issue, with federal Labor publicly declaring their support for such a regime (The Australian, 29 July 2000, p. 30).

\section{The public service partnership: Administrative mobilisation}

In implementing enduring policy reform, the importance of 'administrative mobilisation' is now recognised (Lindquist and Wanna 2011, p. 3). While Kemp may have won the political battle, the administrative task of developing the benchmarks and calibrating individual state and territory tests for national comparability was a hard slog over many years, engaging the attention of senior bureaucrats, their technical staff and external psychometric experts. Kemp's department (DEETYA and later DETYA) was initially slow to respond

\footnotetext{
21 This was aired on the Four Corners program in August 1999 and also in the media in the previous month. Clearly many in the education community were concerned that the Minister did intend to use his abilities to withhold funding. In 1997, Kemp had stated in a media release that if any state or territory did not provide an adequate detailed plan, 'the Federal Government would review how its funding could best be used to ensure each child's needs were met': ABC 1999, pp. 8-9; The Australian, 20 July 1999, p. 6; Kemp, Media Release, 16 September 1997.

22 Although Queensland, Victoria and Tasmania were initially of a similar political leaning, Kemp appeared to bring his agenda unilaterally to MCEETYA meetings, with the exception of his first meeting in 1996 when he joined with Bob Quinn (the Queensland minister) to bring a critical package of resolutions on literacy: Peach 1998, pp. 9-10.
} 
to their Minister's interest in literacy, given the more hands-off role that the Commonwealth had tended to play in schooling. But, by mid-1996, a dedicated literacy team had been brought together, combining strategic policy skills, Commonwealth/state experience and literacy expertise.

The partnership which key departmental officers forged with Kemp and his key advisers was critical to the long term success of Kemp's agenda. ${ }^{23}$ Kemp had a clear set of beliefs as to the respective roles of minister and public servants; in particular, he believed that ministers should control policy development, while the public service provided technical advice. In his 1988 book, Kemp had argued policy advice required 'a [political] value component' supplied by ministers and their staffers to complement the department's technical advice (Kemp 1988, pp. 309-10). The DEETYA secretary, Steve Sedgwick, considered that his Minister had a very clear view on how the department could support his agenda, reflected in the open and robust discussions which he and the relevant branch head Evan Arthur were able to have with Kemp and his Chief of Staff Roskom, as Kemp teased out his agenda and took advantage of political and administrative opportunities (Sedgwick 2012; Arthur 2012).

In supporting their Minister at ministerial council meetings, DEETYA/DETYA were known for their tightly organised approach to the MCEETYA processes and the associated meetings of chief education officers. Given the complex technical issues involved, the development of the benchmarks and reporting arrangements necessitated the establishment of a separate Benchmarking Task Force in which DEETYA officers played a more active role than they had taken previously. Moreover, as Bill Daniels (then in charge of the schools branches in DETYA) has recalled, Commonwealth/state bureaucratic interactions during the Kemp years were characterised by considerable antagonism given the political environment (Daniels 2013). The pressure of the constant negotiations, consultations and problem solving required within these various official forums was captured in Sedgwick's undoubtedly understated comment in the department's 2000-01 annual report that while the changes to a stronger accountability framework in schooling were usually pursued collaboratively in Commonwealth/state forums, this was 'not without times of tension and difficulty' (DETYA 2001). His counterpart in Queensland, Peach, had indeed sharply reminded an educators' conference in May 1998 that the Commonwealth had no delivery responsibilities in schooling, although he assured his audience that his Benchmarking Taskforce believed that 'a solution is possible and attainable [on the benchmarking exercise]' (Peach 1998, pp. 8, 15).

23 When Kemp first became Minister, the Secretary of the department was Sandy Hollway, who supported Kemp through the early critical years of his schooling reforms but left in 1997 to become the CEO of the Sydney Organising Committee for the Olympic Games. 
The priority the department attached to the literacy agenda in its work program was reflected in the space devoted to recording progress on the literacy and numeracy benchmarks and associated initiatives in its annual reports each year. Literacy, for instance, featured continuously in the Secretary's report on the portfolio's major developments and achievements. Utilising the capacity under the new Literacy Program for national projects, the department commissioned and published a considerable body of research on literacy issues such as early childhood literacy development and the literacy development of boys (DETYA 2002, chapter 4, outcome 1; Harrington and McDonald 1999). To assist in communicating the Minister's agenda, the department took the further step of releasing departmental papers, such as:

- A discussion paper in October 1997 on the allocation of literacy grants (following Kemp's decision to require detailed literacy plans from systems); and

- In February 1998, a policy paper outlining the Commonwealth's literacy and numeracy policy principles and goals, associated funding strategies and particular areas of literacy disadvantage (Harrington and McDonald 1999; Peach 1998, p. 10).

Through these diverse activities, across the first and second terms of the Howard government, the department at both executive and officer level had clearly engaged very actively with their Minister's policy interest and had adapted to Kemp's particular ministerial style, the urgency of his time horizons and the highly technical nature of this policy issue. The close working relationship was recognised not only by Kemp, who has acknowledged the role of the department (and especially Dr Arthur's work) in the development of national testing as 'tremendously important', but also by state officials (Kemp 2012; Boston 2013).

\section{Pragmatic federalism in action}

This examination of David Kemp's literacy reforms has highlighted that, notwithstanding their roots in Liberal philosophy of individual advancement, a highly pragmatic approach was adopted by Kemp to drive them through. This pragmatic approach, in which the individual policy problem was given primacy over the theoretical formulation of the problem and potential remedy, has been discerned in the broader policy agendas of the Howard government (Hollander and Patapan 2007, pp. 290-291).

Table 1 summarises the features of Kemp's approach. His first step was to identify - or, as his opponents would have said, to construct - the literacy levels of primary school children as a significant public problem, beginning with his development of the opposition's election platform and manifested very early in 
his ministerial term by what was perceived publicly as his 'crusade' on literacy. In championing literacy standards as a major policy issue, he was assisted by an international and domestic environment which was increasingly supportive of standardised assessment and national reporting as the means of extending the accountability of teachers, schools and systems. Kemp brought a particular bent towards the acquisition of a supportive evidence base to underpin his agenda and to generate public debate; the planned National Literacy Survey of primary school children was a timely platform for this. His controversial decision to insist on presenting a clear line on the survey's results through a specially commissioned (second) report, and then to announce the results on a populist national television program in September 1997, powerfully cemented in the public mind that Australian schools were experiencing a 'literacy crisis'. In 't Hart's view, 'turning up the heat' on your political adversaries is 'a sine qua non of reformist leadership' and Kemp would presumably have endorsed this position ('t Hart 2011, p. 203).

Kemp believed that winning the public debate was crucial to achieving reform in a policy area with powerful interest groups. Although it alienated the education community, it ensured that state ministers could not hold out against his determination not only to establish national benchmarks for literacy and numeracy at critical years of schooling but to report nationally on performance by equating the results of their individual state tests. Unlike the health sector, where a deep evidence base demonstrating which interventions work has been carefully built up through bureaucratic and academic partnerships over several decades, evidence in the schools sector is a far more contested area and frequently challenged as politically motivated (see, for example, Vromen et al. 2009, pp. 17, 331, 335). While Kemp undoubtedly had a deep attachment to discovering and communicating the evidence on literacy attainment, which he believed had been kept from the public domain (Kemp 2012), his methods were seen by many not only as polarising and divisive but also as motivated by his underlying political agenda. 
New Accountabilities, New Challenges

Table 1: Kemp's literacy reforms: Pragmatic federalism in action

\begin{tabular}{|c|c|}
\hline $\begin{array}{l}\text { Elements of reform } \\
\text { approach }\end{array}$ & How Kemp pursued these \\
\hline $\begin{array}{l}\text { 1. Positioning literacy } \\
\text { as an urgent policy } \\
\text { problem }\end{array}$ & $\begin{array}{l}\text { a. Identified literacy standards as a priority in Opposition election } \\
\text { platform } \\
\text { b. Capitalised on national and international initiatives in standardised } \\
\text { assessment } \\
\text { c. Publicly 'crusaded' for literacy as a core skill for individual and for } \\
\text { national productivity. }\end{array}$ \\
\hline $\begin{array}{l}\text { 2. Marshalling and } \\
\text { publicising the } \\
\text { evidence }\end{array}$ & $\begin{array}{l}\text { a. Built strong (but contested) evidence base, taking advantage of } \\
\text { National Literacy Survey of primary schoolchildren (the first in } 16 \\
\text { years) } \\
\text { b. Ensured that the survey results clearly showed the proportion of } \\
\text { children who were below the relevant benchmark, despite state } \\
\text { objections and academic critics } \\
\text { c. Used popular media to highlight 'alarming' results and win public } \\
\text { debate. }\end{array}$ \\
\hline $\begin{array}{l}\text { 3. Getting the } \\
\text { Commonwealth } \\
\text { politics right }\end{array}$ & $\begin{array}{l}\text { a. Ensured his education agenda was politically aligned with } \\
\text { government's and Prime Minister's priorities in terms of } \\
\text { competition and choice agendas } \\
\text { b. Positioned and 'sold' literacy reforms as in the 'national interest' }\end{array}$ \\
\hline $\begin{array}{l}\text { 4. Getting state } \\
\text { agreement }- \text { the } \\
\text { carrot }\end{array}$ & $\begin{array}{l}\text { a. Used evidence and persuasion in ministerial meetings, particularly } \\
\text { ministerial-only sessions } \\
\text { b. Secured additional Commonwealth funding for literacy and } \\
\text { numeracy } \\
\text { c. Cultivated non-government sector to ensure their involvement in } \\
\text { national testing. }\end{array}$ \\
\hline $\begin{array}{l}\text { 5. Getting state } \\
\text { agreement }- \text { the } \\
\text { stick }\end{array}$ & $\begin{array}{l}\text { a. Imposed conditions on states for funding, e.g. detailed plans for } \\
\text { literacy improvement } \\
\text { b. 'Stalking horse' - made threats to withhold or tie literacy funds } \\
\text { to literacy improvement } \\
\text { c. Legislated as Commonwealth funding requirement for education } \\
\text { systems to report literacy and numeracy performance. }\end{array}$ \\
\hline $\begin{array}{l}\text { 6. The public service } \\
\text { partnership }\end{array}$ & $\begin{array}{l}\text { a. Held strong views on the minister's responsibility for policy } \\
\text { development. } \\
\text { b. Had a good working relationship with department - saw officers } \\
\text { as administrative champions, and was comfortable with robust } \\
\text { discussions } \\
\text { c. The department, in turn, mobilised to prioritise literacy in its work } \\
\text { program and Commonwealth/state negotiations. }\end{array}$ \\
\hline
\end{tabular}

Although Kemp initially operated 'below the radar' within the new Howard government in prosecuting such a determined agenda, his success in generating the pressure of public opinion for action on literacy also built his internal political capital, evidenced in his promotion to the senior ministry. Howard's public recognition of Kemp's achievements on the literacy agenda indicated the support Kemp acquired within the cabinet, and certainly his schooling reforms were seen as closely aligned with the government's adoption of choice and 
competition as two of its political mantras. For the Coalition, the public support for their schools agenda represented an electoral advantage, by eroding what had traditionally been seen as a core strength for Labor (Senior 2008, p. 221).

In the federal arena, Kemp was willing to employ the range of powers available to him as a Commonwealth minister, in order to secure state cooperation. He controlled the agenda by negotiating directly with his ministerial counterparts; there was at that stage no 'human capital' agenda within the Council of Australian Governments to buttress, or alternatively derail, his plans. His ability to understand both the research and technical aspects of literacy was a powerful asset in arguing the case in ministerial council meetings, particularly in ministerial-only meetings or dinners. On certain key issues, such as the decision to retain state tests, he made concessions, recognising, for example, that a fully national test 'was a step too far at that time' (Kemp 2012). He brought additional funding and a greatly heightened profile for school literacy to the negotiating table, which helped to build support from the non-government school sector. Conversely, Kemp put as much pressure as he could bring to bear on his state counterparts and on non-government school systems to agree to his strategies on literacy improvements, such as the legislated conditionality of providing an annual plan to access Commonwealth literacy program funding and annual reporting against performance targets. Although his department had not initiated the work on literacy, their role as administrative champions was vital, particularly in terms of their involvement in the technical detail underpinning the development of the literacy and numeracy benchmarks and the national equating of state test results. This served to maintain the momentum on national assessment, against resistance from state bureaucrats and ministers, for whom testing results were high stakes and a threat to their administrative or political capital. ${ }^{24}$ If reforms involve 'wars not battles', this sustained attention to implementation was intrinsic to overcoming opposition to such systemic change ('t Hart 2011, p. 209).

Yet despite such sustained attention from Kemp and his department over more than five years, literacy reform remained an unfinished agenda when he left the portfolio in November 2001 (to move to the environment portfolio) and the public spotlight moved to other schooling issues. In November 2004, following his retirement from politics, he was quoted in The Australian as laying the blame at the door of state bureaucrats and teacher unions for this failure to maintain the momentum to lift literacy levels, exemplified in the extended delays by the states in publishing nationally the results of the literacy tests (The Australian, 18 November 2004, p. 11). It was not until 2008, under the leadership of Julia Gillard, Minister for Employment, Education and Workplace Relations and

24 The high stakes involved have been highlighted by Dr Bob Lingard and a visiting UK academic in 2010: Lingard 2009, pp. 13, 19; Robin Alexander quoted in SEEWRC 2010, p. 41. 
Deputy Prime Minister in the new Rudd Labor government, that a fully national test (NAPLAN) was conducted, and this was followed by the establishment of a national body (the Australian Curriculum and Assessment Reporting Agency) and a national website, My School, which enabled comparative reporting on literacy and numeracy results at an individual school level. The national assessment regime has also catalysed other reforms - in Queensland, for example, the introduction of the benchmarks and national reporting impelled a major reconsideration of the educational disadvantage faced by its students in having one fewer year of compulsory schooling; Peter Beattie's Labor government finally took the step of adding this additional year, at least partly to enable parity in national reporting.

While Howard may have lauded Kemp's achievements in literacy reform at the time, he did not refer to this singular achievement in his subsequent autobiography. ${ }^{25}$ While there has been broader acknowledgement of the profound impact (both positive and negative) of the introduction of national literacy and numeracy testing and reporting as an accountability tool through output measurement, Kemp's driving role has rarely been highlighted, despite the public recognition during his time as minister. ${ }^{26}$ From his perspective as an educational assessment expert closely involved in national testing, Masters certainly regards the 'Kemp years' as 'pivotal' in the development of literacy and numeracy performance standards and reporting (Masters 2012). Arguably, the Minister (with assistance from his department) displayed what Lindquist and Wanna have described as the qualities for durable policy reform: 'anticipation, contingency planning, considerable prudential judgment and strategic leadership' ${ }^{27}$

\section{Epilogue}

In July 1999, Kemp had predicted that the introduction of testing would 'establish a new benchmark ... against which the success of policies in future years is going to have to be measured' (ABC, 1999, p. 8). Yet notwithstanding

\footnotetext{
25 The ex-Prime Minister does not mention Kemp in his capacity as Education Minister, and the one schools policy of which he remains 'intensely proud' is the rapid expansion of independent schools charging low to moderate fees: Howard 2010, p. 243, 487.

26 In his 2008 article on school assessment, Steve Dowling recognised the profound impact of the introduction of testing in the late 1990s and acknowledged that Kemp was Education Minister at the time when national testing was introduced, although he did not directly describe his role in this reform. There has been some recent recognition that NAPLAN was built on the 'Howard government's initiative': see Bamford 2010; Dowling 2008, p. 3.

27 Educational policy-making tends to be critiqued by academic observers as 'messy' and 'ad hoc' or, alternatively, driven by hostile announcements without sufficient attention to implementation issues and risks: Lindquist and Wanna 2011, pp. 3, 11; Reid 1998, p. xi.
} 
Kemp's spotlight on Australia's literacy achievements, the nation's performance as measured by the international benchmark of the OECD's Programme for International Student Assessment tests, declined between 2000 and 2009. ${ }^{28}$

The reasons for the decline are still being debated. One possibility is that the benchmarks created by the Commonwealth and states were set too low, producing little urgency for change in teaching and school management practices from either education bureaucracies or their ministers. It could also be that schools are not employing the most effective literacy strategies, or that other changes in the student population or school structure have offset the increased literacy focus. The most authoritative comment has come from a paper prepared for the panel conducting the Review of Funding for Schooling (the Gonski review), established by the Gillard Labor government. This found evidence that the decline in reading and mathematics was linked to the increased concentration of disadvantaged children in largely government schools. This change was, in turn, partly the result of other Kemp reforms which enabled parents to exercise choice in the school their children went to, the corresponding growth of the non-government school sector and a resulting loss of middle class children from the public system (Gonski et al. 2011, pp. 20-22).

If this is true, it would tend to suggest that, ironically, David Kemp's literacy reforms, as important as they were, were undermined by parental choice - the other key plank in his schooling reform agenda.

\section{References}

Alloway, N. and P. Gilbert 1998, ‘Reading Literacy Test Data: Benchmarking success?', The Australian Journal of Language and Literacy 21(3).

Argy, F. 1998, Australia at the Crossroads: Radical free market or progressive liberalism?, Allen and Unwin, St Leonards.

ABC 1999, Four Corners transcript: 'War of the Words', 9 August. Available at: http://www.abc.net.au/4corners/stories/s44493.htm.

Anderson, G. and A. Parkin 2010, 'Federalism: A fork in the road?', in C. Aulich and M. Evans (eds), The Rudd Government: Australian Commonwealth Administration 2007-10, ANU E Press, Canberra.

Arthur, E. 2011, interview by Trish Mercer, 31 August 2011.

28 Hollander and Patapan highlight the risk that a pragmatic federal approach, especially where there are crisis driven policy formulations, can have unintended consequences: Hollander and Patapan 2007, p. 291. 
Arthur, E. 2012, interview by Wendy Jarvie and Trish Mercer, 4 May 2012.

AUSPELD (The Australian Federation of SPELD Associations) 2005, 'Submission to the National Inquiry into the Teaching of Literacy'. Available at: http:// auspeld.org.au/wp-content/uploads/2010/08/2005_auspeld_nat_inq.pdf.

Australianpolitics.com 2001, 'Election policy speech by John Howard', 28 October. Available at: http://australianpolitics.com/2000/10/28/johnhoward-election-policy-speech.html.

Bamford, P. 2010, 'Teaching to the Test', 7 April. Available at: http://inside.org. au/teaching-to-the-test/.

Boston, K. 2013, Interview by Wendy Jarvie and Trish Mercer, 21 February 2013.

Channel Nine 1999, Sunday transcript, 13 June 1999. Available at: http://sgpl. paddington.ninemsn.com.au/sunday/political_transcripts/transcript_340. asp.

Comber, B., B. Green, B. Lingard and A. Luke 1998, 'Literacy Debates and Public Debates: A question of "crisis"?', in A. Reid (ed.), Going Public: Education policy and public education in Australia, Australian Curriculum Studies Association in association with the Centre for the Study of Public Education at the University of South Australia, Canberra.

Daniels, B. 2013, Interview by Trish Mercer, 3 April 2013.

DEETYA 2002, 'Annual Report'. Available at: http://www.dest.gov.au/portfolio_ department/dest_information/publications_resources/profiles/deetya_ annual_report.

DETYA (Department of Employment, Training and Youth Affairs) 1999, 'Annual Report'. Available at: http://www.voced.edu.au/content/ngv22140.

DETYA 2001, 'Annual Report'. Available at: http://www.voced.edu.au/content/ ngv20768.

Dowling, A. 2008. Output Measurement in Education, Policy Analysis and Program Evaluation, Australian Council for Educational Research. Available at: http://research.acer.edu.au/policy_analysis_misc/2.

Gill, M. 1998, 'Who Set the Benchmarks?: Analysing the national literacy agenda', English in Australia 121. Available at: http://www.aate.org.au/ documents/item/477. 
Gonski, D., K. Boston, K. Greiner, C. Lawrence, B. Scales and P. Tannock 2011, 'Review of Funding for Schooling: Final report'. Available at: http://www. schoolfunding.gov.au/review.

Harrington, M. and S. McDonald 1999, Literacy: A chronology of selected research and Commonwealth policy initiatives since 1975, Parliamentary Library, Parliament of Australia, Canberra. Available at: http://aph.gov. au/parlinfo/download/library/prspub/QWJ06/upload_binary/qwj066. pdf;fileType=application/pdf.

Hollander, R. and H. Patapan 2007, 'Pragmatic Federalism: Australian federalism from Hawke to Howard', The Australian Journal of Public Administration 66(3).

Howard, J. 2010, Lazarus Rising: A personal and political autobiography, Harper Collins, Pymble.

Kelly, P. 2006, 'Re-Thinking Australian Governance: The Howard legacy', Australian Journal of Public Administration 65(1).

Kemp, D. A. 1988, Foundations for Australian Political Analysis Politics and Authority, Oxford University Press, South Melbourne.

Kemp, D. A. 1991, 'Mediocrity or Excellence', address to National Press Club, 3 July, recording held by National Library of Australia, Canberra.

Kemp, D. A. 'Media releases 1996-99', previously in Minister Archive on Commonwealth Department of Education, Science and Training (DEST) website.

Kemp, D. A. 1999, 'Knowledge and Innovation: A policy statement on research and research training', Department of Education, Training and Youth Affairs.

Kemp, D. A. 2012, interview by Wendy Jarvie and Trish Mercer, 6 August 2012.

Kemp, D. A. 2013, personal communication, 19 February 2013.

Liberals and Nationals Election Platform 1996, 'Schools and TAFE'. Available at: http://parlinfo.aph.gov.au/parlinfo/download/library/partypol/1279303.

Lindquist, E. and J. Wanna 2011, 'Delivering Policy Reform: Making it happen, making it stick', in E. Lindquist, S. Vincent and J. Wanna (eds), Delivering Policy Reform: Anchoring significant reforms in turbulent times, ANU E Press, Canberra.

Lingard, B. 2009, 'Testing Times: The need for new intelligent accountabilities for schooling', QTU Professional Magazine, November. 
Lo Bianco, J. and P. Freebody 1997, Australian Literacies: Informing national policy on literacy education, Language Australia, Melbourne.

MCNSELS (Management Committee for the National School English Literacy Survey) 1997, 'Mapping Literacy Achievement Results of the 1996 National School English Literacy Survey', Commonwealth Department of Employment, Education, Training and Youth Affairs, Canberra.

Martin, R. 1997, 'Manufacturing the Literacy Crisis', Australian Educator: The magazine of the Australian Education Union 16.

Masters, G. 2012, Interview by Wendy Jarvie and Trish Mercer, 28 June 2012.

Masters, G. and Forster, M. 1997, 'Literacy Standards in Australia', Dept of Employment, Education, Training and Youth Affairs (DEETYA). Available at: http://research.acer.edu.au/cgi/viewcontent.cgi?article $=1005 \&$ context $=\mathrm{m}$ onitoring_learning\&sei-redir $=1$ \&referer $=\mathrm{http} \% 3 \mathrm{~A} \% 2 \mathrm{~F} \% 2 \mathrm{Fwww}$.google. com.au \% 2Fsearch \% 3Fclient \% 3Dsafari \% 26rls\%3Den \% 26q\%3DLiteracy \%2BStandards \% 2Bin \%2BAustralia \% 25E2\%2580\%2599\%2C\%2Bin \% $2 \mathrm{~B}$ Monitoring \%2BLearning \%26ie \%3DUTF-8\%26oe\%3DUTF-8\%26gfe_rd \% 3Dcr \% 26ei \% 3DVOsgVObTGsiN8QenrYCgBw\#search=\%22Literacy \% 20 Standards\%20Australia'\%2C\%20Monitoring \%20Learning \%22.

MCEECDYA (Ministerial Council for Education, Early Childhood Development and Youth Affairs) 1996-2001, 'Information Statements Released by Former Ministerial Councils', Ministerial Council for Education, Employment, Training and Youth Affairs. Available at: http://www.mceecdya.edu.au/ mceecdya/about_mceecdya,11318.html.

National Independent Schools Council Board Minutes, various dates. Independent Schools Council of Australia, Canberra.

Nous Group, Melbourne Graduate School of Education (MGSE) and National Institute of Labour Studies (NILS) 2011, 'Schooling Challenges and Opportunities: A report for the review of funding for schooling panel', August. Available at: http://www.Nousgroup.com.au/NILS/MGSE.

Peach, F. 1998, 'The National Literacy and Numeracy Strategies: Implications for educators', Unicorn Journal of the Australian College of Educators, 24(2), Special Issue: Literacy and Numeracy.

Reid, A. 1998, 'Preface', in A. Reid (ed.), Going Public: Education policy and public education in Australia, Australian Curriculum Studies Association in association with the Centre for the Study of Public Education at the University of South Australia, Canberra. 
Sedgwick, S. 2012, interview by Wendy Jarvie and Trish Mercer, 3 August 2012.

SEEWRC (Senate Education, Employment and Workplace Relations Committee) 2010, 'Inquiry into Administration and Reporting of NAPLAN Testing', Parliament of Australia.

Senior, P. 2008, 'Liberal Party Policy Challenges', in P. Van Onselen (ed.), Liberals and Power: The road ahead, Melbourne University Press, Melbourne.

SCRRCSSP (Steering Committee for Review of Commonwealth/State Service Provision) 1998, 'Report on Government Service Provision', Commonwealth Government.

Spring, G. 2013, Interview by Wendy Jarvie and Trish Mercer, 25 March 2013.

't Hart, P. 2011, 'Epilogue: Rules for reformers', in E. Lindquist, S. Vincent and J. Wanna, Delivering Policy Reform: Anchoring significant reforms in turbulent times, ANU E Press, Canberra.

Vromen, A., K. Gelber and A. Gauja 2009, Powerscape: Contemporary Australian politics, Allen and Unwin, Crows Nest.

Watson, L. 2011, 'Federalism and Education Policy: The USA and Australia compared', paper presented to School of Business, University of New South Wales, Canberra, 19 May.

Wilkinson, I., B. Caldwell, R. Selleck, J. Harris and P. Dettman 2007, A History of State Aid to Non-Government Schools in Australia, Department of Education, Science and Training, Commonwealth of Australia, Canberra. 
This text taken from New Accountabilities, New Challenges, edited by John Wanna, Evert A. Lindquist and Penelope Marshall, published 2015 by ANU Press, The Australian National University, Canberra, Australia. 